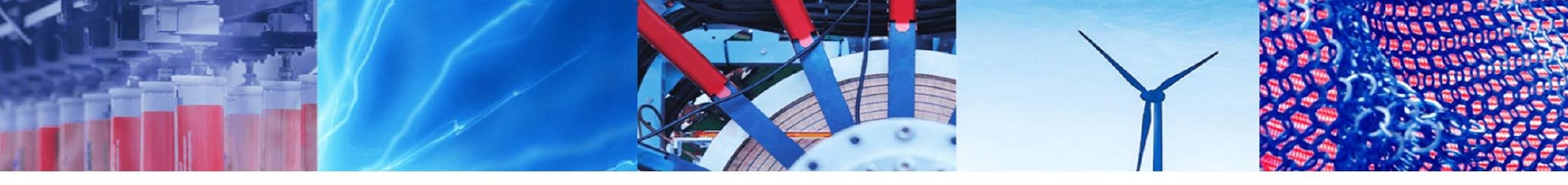

Research Article

\title{
Factors affecting defects occurrence in the construction stage of residential buildings in Gaza Strip
}

\author{
Bassam A. Tayeh ${ }^{1} \cdot$ Ahsen Maqsoom ${ }^{2}$ (D) Yazan Issa Abu Aisheh ${ }^{3} \cdot$ Mansour Almanassra $^{1} \cdot$ Hammad Salahuddin $^{2}$. \\ Muhammad Irshad Qureshi ${ }^{4}$
}

Received: 26 September 2019 / Accepted: 3 January 2020 / Published online: 8 January 2020

(c) Springer Nature Switzerland AG 2020

\begin{abstract}
The building defects are always of great concern for construction industry as they cause delays before handing over and increase maintenance costs during occupancy of the buildings. Due to the rapid development and population growth in Gaza Strip, many residential buildings and housing projects are being constructed in a short space of time, especially after Gaza war in 2014. Therefore, many errors and defects are expected to arise during the construction stage. The aim of this paper is to identify and rank the factors affecting the defects occurrence in the construction stage of the residential buildings in Gaza Strip. A survey was conducted in 134 randomly selected engineers working for engineering offices as design engineers, supervisors and project managers in Gaza Strip. The study revealed five most effective main factors during the construction stage, namely construction materials, factors due to inspections, factors due to construction equipment, factors due to constructions and factors due to construction management, respectively. The most important factors in each group were poor soil compaction, exceeding the allowable limits of verticality of the structural elements, insufficient reinforcement concrete cover, owner's negligence of inspections, absence of engineer in most of construction phases, using expired material, material or component failure, using corroded or second-hand reinforcement steel, using materials not of acceptable quality and not conforming to the specifications or design and lack of required equipment. This research is the first attempt at identifying factors affecting defect occurrence in the construction stage of residential buildings of the developing countries. The findings will be useful for the construction firms and regulatory bodies to deal with the critical factors affecting defect occurrence and device such policies that improve the design and construction of residential buildings.
\end{abstract}

Keywords Factors · Construction stage $\cdot$ Defects occurrence $\cdot$ Gaza Strip

\section{Introduction}

The fast growth of population and technological advancement in all lifestyles have made human to adapt to the environmental changes and ensure a better form of housing to accommodate himself and his family [1]. Presently, humans are not seeking housing facilities only but are very interested in the provision of quality housing facilities for both function and aesthetics [2]. The functionality of the residential building and its coverings depend on its ability to act as an air barrier, thermal barrier and weather barrier. This includes the building security and safety from the fire in addition to the appearance and the structural stability [3].

There is enough evidence regarding the defects found in the new residential buildings; such defects demand

$\triangle$ Ahsen Maqsoom, ahsen.maqsoom@ciitwah.edu.pk| 'Department of Civil Engineering, Islamic University of Gaza, Gaza,

Palestine. ${ }^{2}$ Department of Civil Engineering, COMSATS University Islamabad, Wah Campus, Wah Cantt, Pakistan. ${ }^{3}$ Department of Civil Engineering, Middle East University, Amman, Jordan. ${ }^{4}$ Department of Civil Engineering, University of Engineering and Technology, Taxila, Pakistan. 
significant attention [4]. Their occurrences have serious consequences for construction projects' parties and end users and contribute to low reputation for quality fulfillment in the housing sectors in many countries [5].

Different studies have been conducted to identify causes of defects through mathematical models; for example, [6] proposed a mathematical model to estimate the frequency and magnitude of conditions causing defects. [7] discussed factors contributing to poor workmanship and possible solutions to minimize them. Besides the final cost of product, defective building construction has implications throughout the life cycle of the building in the shape of maintenance cost [8], which can be substantial. Defective construction may lead to the failure of the structure completely in the end. The construction industry in whole of the world is getting modern, advanced and growing daily with the help of information technology systems [9]. Housing project represents a significant part of our society. Construction defects become a global issue faced by researchers and practitioners around the world. Defects can affect the success of construction project significantly. More specifically, it has a main impact on the construction time, construction cost, sustainability aspects, productivity and customer satisfaction [5].

Although there are many studies about defects in construction projects during design and construction phases, no one before in Gaza Strip in particular has taken the residential buildings' civil design and construction's defects into considerations. Design and construction defects can be avoided if there is an appropriate planning and sufficient knowledge during both phases of civil design and construction of the residential buildings. In order to achieve that, a study needs to be conducted in order to identify factors affecting civil design and construction and leading to defects occurrence in the residential buildings sector in Gaza Strips to help avoid them further.

The objective of this study is to identify and rank the factors affecting the defects occurrence in the construction stage of the residential buildings in Gaza Strip. Particularly, it investigates the factors related to civil construction, construction inspection, construction management, construction material and construction equipment.

\section{Literature review}

Ojo and ljatuyi [31] defined defects as "faults, which may reduce the strength of a construction work, durability or usefulness". It is among the most common problems that construction projects suffer from [10-18]. Chong and Low [19] found that "most of the defects due to human factors were caused solely by 'forgetfulness and carelessness,' $29 \%$ by lack of knowledge, and a very small percentage were intentional. As for workmanship defects, lack of motivation dominated the costs, but the presence of risks directly increased the chance of defects."

Carelessness has been stated to be the most important cause of construction defects [20]. Jingmond and Ågren [21] conducted a study to identify primary root causes of defects and found that the causes of defects mainly reside in endogenous factors within the organizations. According to Waziri [22], it was noticed that many building defects could be explained entirely or partly because of readily identifiable errors in construction, which could have been foreseen and hence avoided. The importance of different defects arising from construction process has been established and identified as critical to the maintenance of residential building. The topmost defects have been determined to be: poor construction work supervision, use of defective construction materials, poor site quality control, defects due to specification and use of untested and new materials and incompetent workforce for construction. However, Ahzahar [23] found that low quality of construction materials is the most common factor that leads to the building defects and failures. Bakri and Mydin [24] divided the defects into two main categories; these categories are structural defect and nonstructural defect. Structural defect means any defect in a structural element of a building that is attributed to defective material, defective or faulty workmanship, defective design and sometimes any combination of these. The structure of building includes columns, earth retaining walls, flat slabs and beams.

Structural defects can be categorized as cracks in walls (superstructure), cracks in foundations (substructure) and cracks in floor or slabs (superstructure). These defects can result from inadequate soil analysis, use of defective materials and inappropriate site selection. However, nonstructural defect in a residential building is defined as a defect in a nonstructural element of the building because of defective residential building work. Nonstructural defect includes defect in plaster works, dampness in old structures and defects in brickwork.

According to Al-Farra [25], the other source of the high cost of maintenance process is the defaults in construction phase, which may be due to many factors such as contractor performance, nonuse of appropriate materials, poor supervision and ineffective use of equipment. As known, the construction environment is constantly changing, and the authorities' actions continuously give new conditions. Simultaneously, competition between companies may become a stronger factor that leads the contractor to accept the bid with low margin of profit. Studies show that the construction defects cost is in the range of $5-10 \%$ of the production cost. Therefore, knowledge of the causes of these defects is necessary for choosing adequate measures. 
Construction defects due to Waziri [22] arise from several factors, which could be visible to the naked eye or deep hidden within the structure. Construction defects that affect directly the structure performance can be a result of defective design or defective construction. Generally, the construction can be as a design that fails to meet the professional standard and a decision that is not in accordance with codes, among others. Construction failures and defects also may result from poor and misguided decisions of the clients or failure of the design professional to produce complete and accurate design and construction documents, which provide sufficient information for the contractor for building construction. Sometimes, they can be due to the use of nonconforming materials, poor workmanship and design misinterpretation.

According to Assaf et al. [26], defects in the construction stage include (1) defects due to construction inspection based on unqualified inspector, lack of inspection, weakened inspection rule in implementing corrective actions during job execution and proponent (owner) negligence of the importance of inspection; (2) defects due to civil construction based on inaccurate measurement, damaged formwork, excavation tools close to the building, painting in unsuitable conditions or on unsuitable surface, inadequate waterproofing and drainage, insufficient reinforcement concrete cover, cold joints, loss in adhesion between materials, early formwork removal, poor soil compaction, inadequate curing and lack of communication; (3) defects due to specification based on unclear specification, not defining adequate materials, not specifying the QA/QC construction procedure, not specifying the allowable load limits and specifying inadequate concrete mix design; (4) defects due to contractor administration based on not complying with specification, insufficient site supervision, poor communication with the design firm and the owner, unqualified supervision, speedy completion or poorquality work, unqualified workforce and multinational construction experience; (5) defects due to construction material based on differential thermal movements in dissimilar materials, selection of material that is unsuitable for existing climatic conditions, use of nondurable material, use of expired material and poor materials handling storage; and (6) defects due to construction equipment based on improper use of equipment, inadequate performance of equipment and lack of required items of equipment.

\section{Methodology}

To achieve the research objective, a questionnaire survey was conducted by focusing on engineers who are working mainly in the field of structural design and supervision on construction of engineering projects. The study population was taken from formal statistics belonging to Gaza Engineering Association which consists of 205 registered engineering offices in Gaza Strip. The study sample was selected based on the equation [27]. The sample size was calculated from Eq. 1:

$n=\left(\frac{Z}{2 m}\right)^{2}$

where $Z$ is the standard value corresponding to a given level of significance ( $Z=1.96$ for $a 0.05) . m$ (margin error) is expressed as decimal $( \pm 0.05)$.

The sample size is then corrected in the case of the final communities from Eq. 2:

$n=\frac{n N}{N+n-1}$

where $N$ is the sample size, and using the first equation, we find that the sample size is found by Eq. 3 :

$n=\left(\frac{1.96}{2 \times 0.05}\right)^{2} \cong 384$

Since the study population is $N=205$, the size of the modified sample using Eq. 2 is equal to:

$\frac{384 \times 205}{205+384-1}=134$

Although the calculated sample size was 134 engineering offices, the questionnaires were sent to 134 randomly selected engineers working in engineering offices by targeting one engineer in each office to overcome the risk of low participation from offices and to ensure higher reliability and benefits of the study. One hundred eight completed questionnaires were returned, representing a response rate of $80.60 \%$. Fifty percent of job titles of the respondents were supervisors/site engineers, 35.19\% were design engineers and remaining $14.81 \%$ were project managers. Therefore, the majority of the questionnaire respondents were supervisors or engineers in the first rank, the second were design engineers and the rest of them were project managers, which was useful as an indicator to how these respondents dealt before with residential buildings design and construction process in Gaza Strip.

Based on literature review, 44 factors for construction defects were derived after reviewing several previous studies [3, 22-26, 28-34]. These factors were categorized under five main groups and are shown in Table 1. A pilot study was conducted with the ten experts (i.e., consultant engineers) [35-37]. These experts were selected based on their technical and managerial capabilities to ensure quality review of the questionnaire. All experts' proposals have been taken into account preparing the basic data to 
Table 1 List of factors from the literature versus selected factors after pilot study

\begin{tabular}{|c|c|c|}
\hline Factors from the literature & Status & Selected factors after pilot study \\
\hline \multicolumn{3}{|l|}{ Civil construction-related factors } \\
\hline Misinterpretation of design & Selected and clarified & $\begin{array}{l}\text { Misinterpretation of the design leading to wrong con- } \\
\text { struction }\end{array}$ \\
\hline Inaccurate measurement & Modified & Inaccurate dimension projection and measurement \\
\hline \multirow[t]{2}{*}{ Damaged formwork } & Modified & $\begin{array}{l}\text { Damaged or weak formwork due to multiuse of formwork } \\
\text { timber }\end{array}$ \\
\hline & Added & $\begin{array}{l}\text { Exceeding the allowable limits of verticality of the struc- } \\
\text { tural elements }\end{array}$ \\
\hline Poor installation method & Not selected & \\
\hline Excavation tools close to the building & Not selected & \\
\hline $\begin{array}{l}\text { Painting in unsuitable conditions or on unsuitable } \\
\text { surface }\end{array}$ & Modified & $\begin{array}{l}\text { Ignoring isolation works for buried parts of concrete (foot- } \\
\text { ings, ground beams and walls) }\end{array}$ \\
\hline Inadequate waterproofing and drainage & Modified & $\begin{array}{l}\text { Poor roof water drainage system or without foam con- } \\
\text { crete for water drainage slopes and without isolation } \\
\text { works for roof }\end{array}$ \\
\hline Insufficient reinforcement concrete cover & Selected & Insufficient reinforcement concrete cover \\
\hline Cold joints & Selected and clarified & $\begin{array}{l}\text { Cold joints, especially in concrete casting, due to late } \\
\text { concrete arrival }\end{array}$ \\
\hline Loss in adhesion between materials & Modified & $\begin{array}{l}\text { Loss in adhesion between concrete and finishing materi- } \\
\text { als due to oil painting of formworks timber or soft faces }\end{array}$ \\
\hline Early formwork removal & Selected & Early formwork removal \\
\hline Poor soil compaction & Modified & $\begin{array}{l}\text { Poor soil compaction or backfilling without compaction } \\
\text { and layers }\end{array}$ \\
\hline Inadequate curing & Modified & $\begin{array}{l}\text { Inadequate water curing of different concrete and finish- } \\
\text { ing works }\end{array}$ \\
\hline Overloading & Modified & Overloading of building during the construction stage \\
\hline Moisture penetration through the building envelope & Not selected & \\
\hline Lack of communication & Not selected & \\
\hline Improper roof installation & Not selected & \\
\hline Specifying inadequate concrete mix design & Not selected & \\
\hline \multicolumn{3}{|l|}{ Construction inspection-related factors } \\
\hline Lack of inspection & Modified & Lack of inspection and material testing \\
\hline Unqualified inspector & Selected and clarified & $\begin{array}{l}\text { Unqualified inspector, especially in concrete cube prepa- } \\
\text { ration }\end{array}$ \\
\hline $\begin{array}{l}\text { Proponent (owner) negligence of the importance of } \\
\text { inspection }\end{array}$ & Selected & $\begin{array}{l}\text { Proponent (owner) negligence of the importance of } \\
\text { inspection }\end{array}$ \\
\hline $\begin{array}{l}\text { Weakness of inspection rule in implementing corrective } \\
\text { actions during job execution }\end{array}$ & Modified & $\begin{array}{l}\text { Neglecting inspection results and their recommendations } \\
\text { in implementing corrective actions during job execution }\end{array}$ \\
\hline \multicolumn{3}{|l|}{ Construction management-related factors } \\
\hline $\begin{array}{l}\text { Lack of documentation, standardization, knowledge and } \\
\text { motivation }\end{array}$ & Added & Lack of QA/QC program during construction \\
\hline Poor workmanship & Modified & Poor or unqualified workmanships \\
\hline Inability to read drawings & Selected & Inability to read the drawings \\
\hline $\begin{array}{l}\text { Competition between companies may become a } \\
\text { stronger factor that leads the contractor to accept the } \\
\text { bid with a low margin of profit }\end{array}$ & Selected & $\begin{array}{l}\text { Competition between companies that leads to accept the } \\
\text { bid with low margin of profit, which affects the quality } \\
\text { of construction }\end{array}$ \\
\hline Not complying with specification & Modified & $\begin{array}{l}\text { Not complying with specification and engineer instruc- } \\
\text { tions }\end{array}$ \\
\hline $\begin{array}{l}\text { Communication gap between contractors and design } \\
\text { professionals }\end{array}$ & Selected & $\begin{array}{l}\text { Communication gap between contractors and design } \\
\text { professionals }\end{array}$ \\
\hline Corruption & Selected & Corruption \\
\hline $\begin{array}{l}\text { Insufficient knowledge on construction/fixing of build- } \\
\text { ing element/components }\end{array}$ & Modified & $\begin{array}{l}\text { Ignorance or insufficient knowledge of the methods of } \\
\text { implementation and supporting of high slabs, drop } \\
\text { beams and concrete walls }\end{array}$ \\
\hline
\end{tabular}


Table 1 (continued)

\begin{tabular}{|c|c|c|}
\hline Factors from the literature & Status & Selected factors after pilot study \\
\hline Insufficient site supervision & Modified & Absence of engineer in most of the construction phases \\
\hline Speedy completion or poor-quality work & Selected & Speedy completion or poor-quality work \\
\hline Multinational construction experience & Selected & Multinational construction experience \\
\hline Poor decisions & Modified & Poor or wrong decisions \\
\hline Poor rectification work processes & Modified & $\begin{array}{l}\text { Poor rectification processes of wrong works and failed } \\
\text { concrete elements }\end{array}$ \\
\hline Human intervention & Modified & $\begin{array}{l}\text { Human-side interventions and expression of opinion } \\
\text { without knowledge }\end{array}$ \\
\hline Remedial work & Modified & Cumulative errors \\
\hline Unqualified supervision & Not selected & \\
\hline Faulty construction & Not selected & \\
\hline Unqualified work force & Not selected & \\
\hline \multicolumn{3}{|l|}{ Construction material- related factors } \\
\hline Material failure or component failure & Selected & Material failure or component failure \\
\hline Differential thermal movements in dissimilar materials & Not selected & \\
\hline Poor materials handling storage & Modified & $\begin{array}{l}\text { Poor storage of construction materials and exposure to } \\
\text { weather conditions }\end{array}$ \\
\hline $\begin{array}{l}\text { Selection of material that is unsuitable for existing } \\
\text { climatic conditions }\end{array}$ & Selected & $\begin{array}{l}\text { Selection of material that is unsuitable for existing cli- } \\
\text { matic conditions }\end{array}$ \\
\hline Materials not of acceptable quality & Selected & \multirow{2}{*}{$\begin{array}{l}\text { Using materials not of acceptable quality and not con- } \\
\text { forming to the specifications or design }\end{array}$} \\
\hline $\begin{array}{l}\text { Using materials not conforming to the specifications or } \\
\text { the design brief }\end{array}$ & Merged & \\
\hline Use of expired material & Selected \& clarified & Using of expired material (cement) \\
\hline Steel corrosion & Modified & $\begin{array}{l}\text { Using of corroded steel or second-hand reinforcement } \\
\text { steel }\end{array}$ \\
\hline Erosion of mortar joint in mason works & Selected & Erosion of mortar joint in mason works \\
\hline $\begin{array}{l}\text { Sulfate attack of ordinary Portland cement in walls and } \\
\text { floors }\end{array}$ & Modified & $\begin{array}{l}\text { Lack of using sulfate resistance cement in areas, which is } \\
\text { exposed to sulfate attack }\end{array}$ \\
\hline Use of new and untested materials & Modified & $\begin{array}{l}\text { Using inadequate concrete mix design for structural ele- } \\
\text { ments }\end{array}$ \\
\hline Metal fatigue in fixings & Not selected & \\
\hline Use of nondurable materials & Not selected & \\
\hline \multicolumn{3}{|l|}{ Construction equipment-related factors } \\
\hline Improper use of equipment & Modified & $\begin{array}{l}\text { Improper use of equipment (compactor, concrete pump, } \\
\text { vibrator, concrete mixer, drill, plumb bob...etc.) }\end{array}$ \\
\hline Inadequate performance of equipment & Modified & $\begin{array}{l}\text { Inadequate performance of equipment (compactor, con- } \\
\text { crete pump, vibrator, concrete mixer, drill...etc.) }\end{array}$ \\
\hline Lack of required items of equipment & Modified & $\begin{array}{l}\text { Lack of required equipment (vibrator, drill, mixer, compac } \\
\text { tor, cutting disk, plumb bob...etc.) }\end{array}$ \\
\hline
\end{tabular}

be used in this survey to construct the first version of this questionnaire. This involved deleting, adding, merging or modifying many variables to develop the final version of the questionnaire.

The ten respondents were asked to review the questionnaire and to verify the validity of the questionnaire topics and their relevance to the research objective and to give their advice. Important comments and suggestions were collected and evaluated carefully. At the end of the pilot study, a few minor changes, modifications and additions were accommodated to finalize the questionnaire.
The questionnaire was validated by the criterion-related reliability test, which measures the correlation coefficients between the factors selected for in one group and the whole group, and structure validity test (Spearman test).

The collected raw data were first sorted, edited, coded and then entered into computer software. Two softwares were used, the Excel sheet and SPSS. The ordinal scale is a rating datum, which uses integers in ascending or descending order. The relative important index (RII) was used for the analysis of data. Also analysis of variance (ANOVA) tests, frequencies and percentiles were used. The RII method has 
been widely used in construction research for calculating and formulating attitudes with respect to surveyed variables.

The relative importance index method (RII) was used to determine the ranks of all factors. The relative importance index was computed using the following formula (Eq. 4):

$\bar{X}_{W}=\frac{\sum W}{A N}=\frac{5 n_{5}+4 n_{4}+3 n_{3}+2 n_{2}+1 n_{1}}{5 N}$

where $W$ is the weight given to each factor by the respondents (ranging from 1 to 5), $A$ the highest weight (i.e., 5 in this case), $N$ the total number of respondents, $n_{1}$ number of respondents who strongly agreed, $n_{2}$ number of respondents who do not agree, $n_{3}$ number of respondents who are neutral, $n_{4}$ number of respondents who agree, $n_{5}$ number of respondents who strongly agreed).

The Rll value had a range from 0 to 1 ( 0 not inclusive); the higher the value of RII, the more is the impact of that attribute. RII value ranges between 0 and 1 . The analyzed data were finally presented using descriptive methods for easy interpretation and comparisons. Further, the relative weight $\%$ was calculated by dividing the mean by the number of response options (i.e., 5 in the study) (Eq. 5):

$\mathrm{RII}=($ Mean $\div 5) \times 100 \%$

Respondents were asked to rate each factor on a rating scale (five-point Likert scale) that required a ranking (1-5), where 1 represented "the lowest scale" and 5 represented "the highest scale," as the case might be. The numerical rating scale (five-point Likert scale) was chosen to format the questions of the questionnaire with some common sets of response categories called quantifiers. Those quantifiers were used to facilitate understanding as $\mathrm{RII}=(20-36 \%)$ not important at all, (36-52\%) not important, (52-68\%) moderately important, (68-84\%), important and (84-100\%) very important.

Additionally, one-sample $t$ test was used to determine whether the mean of a factor is significantly different from a hypothesized value 3 (middle value of Likert scale). If the $P$ value (Sig.) is smaller than or equal to the level of significance $a=0.05$, then the mean of a factor is significantly different from a hypothesized value 3 . The sign of the test value indicates whether the mean is significantly greater or smaller than hypothesized value 3 . On the other hand, if the $P$ value (Sig.) is greater than the level of significance $\alpha=0.05$, then the mean a factor is insignificantly different from a hypothesized value 3 .

\section{Results and discussion}

Under this section, the results of analysis are supposed to achieve the aim of the study in addition to the second and third objectives of the research, which are the factors affecting the defects occurrence in the construction stage of the residential buildings in Gaza Strip, and degree of effect of those factors in the construction stages of residential buildings in Gaza Strip.

Five main groups of factors affecting the construction stage were derived after reviewing the literature and the pilot study, which are: (1) civil construction-related factors, (2) construction inspection-related factors, (3) construction management-related factors, (4) construction materials-related factors and (5) construction equipment-related factors. Each main factor has a list of subfactors in which the respondents put their opinions about the importance of each one in contributing defects occurrence during the construction stage of residential buildings in Gaza Strip.

\subsection{Civil construction-related factors affecting the defects occurrence in the construction stage}

From Table 2, it is clear that the arithmetic mean of all the factors was larger than the overall average (3). Therefore, there were significant differences between the civil construction-related factors. The total axis relative weight reached $82.4 \%$, the mean was 4.12 and the standard deviation was 0.74 .

From Table 2, it can be seen that poor soil compacting factor was in the first rank with a relative weight of $88.20 \%$ and this is very logical because most of the backfilling processes in the construction stage of residential buildings in Gaza Strip are executed without real compaction or with poor compaction, which lead to unwanted settlement in the future.

Exceeding the allowable limits of verticality of the structural elements factor was in the second place with a relative weight of $87.60 \%$. Proper verticality of the structural elements is very important to prevent cumulative exceeded deviation about the vertical axis to more than the allowable limits, which appears in the figure of the building and may generate a destructive moment causing overturning of the tall building.

Insufficient reinforcement concrete cover factor was in the third place of importance, which agreed with AlFarra [25] and Assaf et al. [26] results. Sometimes, during construction of the residential buildings and in the absence of engineers, the reinforcement concrete cover of different structural elements is neglected from the 
Table 2 Statistical characteristics of the main civil construction-related factors

\begin{tabular}{|c|c|c|c|c|c|c|c|}
\hline No. & Civil construction-related factors & Mean & SD & $\begin{array}{l}\text { Relative } \\
\text { weight } \\
\%\end{array}$ & Value of the test & $P$ value & Rank \\
\hline 1. & Misinterpretation of the design leading to wrong construction & 4.10 & 0.96 & 82.00 & 8.82 & 0.00 & 9 \\
\hline 2. & Inaccurate dimension projection and measurement & 4.32 & 0.84 & 86.40 & 12.10 & 0.00 & 5 \\
\hline 3. & Damaged or weak formwork due to the multiuse of formwork timber & 4.34 & 0.84 & 86.80 & 12.20 & 0.00 & 4 \\
\hline 4. & Exceeding the allowable limits of verticality of the structural elements & 4.38 & 0.72 & 87.60 & 14.56 & 0.00 & 2 \\
\hline 5. & $\begin{array}{l}\text { Ignoring isolation works for buried parts of concrete (footings, ground } \\
\text { beams and walls) }\end{array}$ & 3.76 & 1.32 & 75.20 & 4.45 & 0.00 & 11 \\
\hline 6. & $\begin{array}{l}\text { Poor roof water drainage system or without foam concrete for water drain- } \\
\text { age slopes and without isolation works for roof }\end{array}$ & 4.00 & 1.19 & 80.00 & 6.46 & 0.00 & 10 \\
\hline 7. & Insufficient reinforcement concrete cover & 4.39 & 1.02 & 87.80 & 10.49 & 0.00 & 3 \\
\hline 8. & Cold joints, especially in concrete casting, due to late concrete arrival & 4.27 & 0.91 & 85.40 & 10.77 & 0.00 & 8 \\
\hline 9. & $\begin{array}{l}\text { Loss of adhesion between concrete and finishing materials due to oil paint- } \\
\text { ing of formworks timber or soft faces }\end{array}$ & 3.56 & 1.13 & 71.20 & 3.79 & 0.00 & 12 \\
\hline 10. & Early formwork removal & 4.31 & 0.92 & 86.20 & 10.83 & 0.00 & 7 \\
\hline 11. & Poor soil compaction or backfilling without compaction and layers & 4.41 & 0.93 & 88.20 & 11.61 & 0.00 & 1 \\
\hline 12. & Inadequate water curing of different concrete and finishing works & 4.31 & 0.79 & 86.20 & 12.64 & 0.00 & 6 \\
\hline \multirow[t]{2}{*}{13.} & Overloading of building during the construction stage & 3.47 & 1.13 & 69.40 & 3.15 & 0.00 & 13 \\
\hline & Civil construction-related factors & 4.12 & 0.74 & 82.40 & 11.60 & 0.00 & \\
\hline
\end{tabular}

contractors or labors for the sake of putting their reinforcement bars well, which causes corrosion in steel reinforcement due to its exposure to environment.

In the fourth and fifth places were factors of damaged or weak formwork due to multiuse of formwork timber, and inaccurate dimension projection and measurement with relative weights of $86.80 \%$ and $86.40 \%$, respectively. Damaged formwork factor was one of the least important factors according to Waziri [22] and Assaf et al. [26]; however, it was considered significant according to Dahanayake amd Ramachandra [30], where most of the defects such as alignment issues and bulging of columns, beams and slabs are due to inadequate formwork according to their research findings. Inaccurate or wrong projecting of measurements and dimensions, as columns axis will cause defects.

Other factors ranked in the top were inadequate concrete curing, early formwork removal and the cold joints with relative weights of $86.20 \%, 86.20 \%$ and $85.40 \%$, respectively. These factors are also important during the construction stages; concrete will not be reaching the intended strength without proper curing. In addition, the too early formwork removal may cause failure of the structure, especially for long-span beams, or cause unwanted deflection, and the cold joint during concrete casting results in improper adhesive between fresh concrete and casted concrete causing cracks or water leakage problems further. These factors were the least important factors according to Assaf et al. [26].
The rest of factors were ranked as less important by respondents as shown in Table 2 , but there was an important factor that ranked in the tenth place which is poor roof water drainage system or absence of foam concrete for water drainage slopes and absence of isolation works for roof. Inadequate waterproofing and drainage factor was considered by Assaf et al. [26] results as a moderately severe factor from the owners' and contractors' perspectives. In the most of residential buildings in Gaza Strip, the roof isolation is neglected by the owners due to finance issues or due to construction of the whole building in multiple stages.

The least important factor was overloading of building during the construction stage with a relative weight of $69.4 \%$. Overloading is not a significant factor during construction process of residential buildings because all the loads during construction are normal and within the allowable loads range.

\subsection{Construction inspection-related factors affecting the defects occurrence in the construction stage}

It can be seen that the arithmetic mean of all the factors was larger than the largest overall average (3) (Table 3). Therefore, there were significant differences between the construction inspection-related factors. The relative weight of the total axis reached $84.75 \%$, the mean was 4.24 and the standard deviation was 0.80 . 
Table 3 Statistical characteristics of the main construction inspection-related factors

\begin{tabular}{|c|c|c|c|c|c|c|c|}
\hline No. & Construction inspection-related factors & Mean & SD & $\begin{array}{l}\text { Relative } \\
\text { weight \% }\end{array}$ & Value of the test & $P$ Value & Rank \\
\hline 1. & Lack of inspection and material testing. & 4.24 & 0.84 & 84.80 & 11.35 & 0.00 & 3 \\
\hline 2. & Unqualified inspector, especially in concrete cube preparation. & 4.02 & 1.01 & 80.40 & 7.75 & 0.00 & 4 \\
\hline 3. & Proponent (owner) negligence of the importance of inspection. & 4.41 & 0.85 & 88.20 & 12.66 & 0.00 & 1 \\
\hline \multirow[t]{2}{*}{4.} & $\begin{array}{l}\text { Neglecting inspection results and their recommendations in } \\
\text { implementing corrective actions during job execution }\end{array}$ & 4.29 & 0.91 & 85.80 & 10.86 & 0.00 & 2 \\
\hline & Construction inspection-related factors & 4.24 & 0.80 & 84.75 & 11.85 & 0.00 & \\
\hline
\end{tabular}

In Table 3, first and the third places were the factors of proponent (owner) negligence of the importance of inspection and lack of inspection and material testing with relative weights of $88.20 \%$ and $84.80 \%$, respectively. The importance of inspection during construction phase agreed with [22]. Most of residential buildings' construction processes in Gaza Strip are executed without materials inspection, and no measures are taken by the owner or the contractors for inspection, which eventually leads to the use of materials nonconforming to the specifications.

On the other hand, if the inspection exists, sometimes the owners or contractors neglect the inspection results as ranked in the second place with a relative weight of $85.80 \%$ and sometimes the inspector is unqualified of the importance of inspection as ranked at last and this agreed with Assaf et al. [26] results, which consider this factor as one of the least important factors.

\subsection{Construction management-related factors affecting the defects occurrence in the construction stage}

Referring to Table 4, it is clear that the arithmetic mean of all factors was larger than the overall average (3). Therefore, there were significant differences in the construction management-related factors. The relative weight of the total axis reached $79.36 \%$, the mean was 3.97 and the standard deviation was 0.5 .

It is clear from Table 4 that the factor of the absence of engineer in most of the construction phases was in the first place with a relative weight of $88.80 \%$; the absence of engineer during construction cannot make sure meeting specifications requirements and quality control standards which eventually leads to improper construction. The importance of this factor is in line with previous studies $[22,23]$.

Table 4 Statistical characteristics for the main construction management-related factors

\begin{tabular}{|c|c|c|c|c|c|c|c|}
\hline No. & Construction management-related factors & Mean & SD & $\begin{array}{l}\text { Relative } \\
\text { weight \% }\end{array}$ & Value of the test & $P$ value & Rank \\
\hline 1. & Lack of QA/QC program during construction & 4.15 & 0.91 & 83.00 & 9.77 & 0.00 & 4 \\
\hline 2. & Poor or unqualified workmanships & 3.98 & 0.99 & 79.60 & 7.62 & 0.00 & 9 \\
\hline 3. & Inability to read the drawings & 3.90 & 1.11 & 78.00 & 6.22 & 0.00 & 10 \\
\hline 4. & $\begin{array}{l}\text { Competition between companies that leads to accept the bid with low } \\
\text { margin of profit, which affects the quality of construction }\end{array}$ & 3.80 & 0.98 & 76.00 & 6.25 & 0.00 & 12 \\
\hline 5. & Not complying with specification and engineer instructions & 4.41 & 0.80 & 88.20 & 13.54 & 0.00 & 2 \\
\hline 6. & Communication gap between contractors and design professionals & 3.71 & 0.97 & 74.20 & 5.66 & 0.00 & 13 \\
\hline 7. & Corruption & 4.10 & 0.79 & 82.00 & 10.67 & 0.00 & 5 \\
\hline 8. & $\begin{array}{l}\text { Ignorance or insufficient knowledge of the methods of implementation } \\
\text { and supporting of high slabs, drop beams and concrete walls }\end{array}$ & 4.03 & 0.87 & 80.60 & 9.12 & 0.00 & 6 \\
\hline 9. & Absence of engineer in most of the construction phases & 4.44 & 0.86 & 88.80 & 12.92 & 0.00 & 1 \\
\hline 10. & Speedy completion or poor-quality work & 4.07 & 0.81 & 81.40 & 10.17 & 0.00 & 7 \\
\hline 11. & Multinational construction experience & 3.25 & 1.01 & 65.00 & 1.93 & 0.06 & 15 \\
\hline 12. & Poor or wrong decisions & 3.88 & 0.87 & 77.60 & 7.76 & 0.00 & 11 \\
\hline 13. & Poor rectification processes of wrong works and failed concrete elements & 4.02 & 0.76 & 80.40 & 10.18 & 0.00 & 8 \\
\hline 14. & Human-side interventions and expression of opinion without knowledge & 3.66 & 0.84 & 73.20 & 6.02 & 0.00 & 14 \\
\hline \multirow[t]{2}{*}{15.} & Cumulative errors & 4.16 & 0.64 & 83.20 & 13.67 & 0.00 & 3 \\
\hline & Construction management-related factors & 3.97 & 0.56 & 79.36 & 13.18 & 0.00 & \\
\hline
\end{tabular}


Not complying with specification and engineer instructions and lack of QA/QC program during construction were two important factors ranked second and fourth with relative weights of $88.20 \%$ and $83 \%$, respectively. Working away from specifications is the most significant defect factor because the specification ensures a proper construction process without any probable defects. QA/QC programs are absent in most of the building processes in Gaza Strip, and the presence of these systems is very important to ensure the good quality of the final product and to ensure reaching the good quality through applying their approaches. The third ranked factor was a cumulative errors factor with a relative weight of $83.20 \%$. Sometimes a small error not taken into consideration leads to a big problem by cumulating on it such as the vertical alignment, elevation errors, projection errors and columns axis errors.

Corruption and poor or unqualified workmanship factors were ranked fifth and ninth with relative weights of $82 \%$ and $79.60 \%$, respectively. These two are main factors leading to defects occurrence during the construction stage, unqualified or corrupted workmanship affect the overall construction process either quality or safety. The importance of corruption factor was also found important by Ahzahar et al. [23] in their study, and the importance of workmanships factor was considered critical in previous studies [22, 28-30]. According to respondents' perspectives, the rest of the factors have a less effect on defect occurrence during the construction process of residential buildings in Gaza Strip. The last ranked factor in this group was multinational construction experience with a relative weight of $65 \%$. In Gaza Strip, there are no multinational workers and the methods of construction are well known to most of the construction workers.

\subsection{Construction materials-related factors affecting the defects occurrence in the construction stage}

It can be seen that the arithmetic mean of all factors was larger than the overall average (3) (Table 5). Therefore, there were significant differences between the construction materials-related factors. The relative weight of the total axis reached $85.05 \%$, the mean 4.25 and the standard deviation 0.62 .

From Table 5, it is clear that the factor of using expired cement was in the first place and the factor of using corroded steel or second-hand reinforcement steel was in the third place with relative weights of $88.20 \%$ and $87.20 \%$. It is noticed that the quality of the construction materials (cement, steel...etc.) is the most important factor in this group due to respondents, and this agrees with Ahzahar [23] and Assaf et al. [26] results.

The second, fourth and sixth places were factors of material failure or component failure, using materials not of acceptable quality and not conforming to the specifications or design and poor storage of construction materials and exposure to weather conditions with relative weights of $87.60 \%, 86.80 \%, 84.80 \%$, respectively. These factors are also significant during construction process; materials failure or materials of not of acceptable quality will definitely cause defects and failure of the structure. Poor storage will lead to material expiry or material failure. The importance of these factors agreed with the results of [26].

In the fifth place is the factor of using inadequate concrete mix design for structural elements with a relative weight of $86.80 \%$. This factor is significant also in concrete elements; using inadequate concrete mix in some structural elements will weaken these elements and affect the strength of them in tolerating the applied loads and may lead to failure of these elements. Assaf et al. [26] results assured that also. The rest factors are ranked in Table 5

Table 5 Statistical characteristics for the main construction materials-related factors

\begin{tabular}{|c|c|c|c|c|c|c|c|}
\hline No. & Construction materials-related factors & Mean & SD & $\begin{array}{l}\text { Relative } \\
\text { weight } \\
\%\end{array}$ & Value of the test & $P$ value & Rank \\
\hline 1. & Material failure or component failure & 4.38 & 0.90 & 87.60 & 11.74 & 0.00 & 2 \\
\hline 2. & Poor storage of construction materials and exposure to weather conditions & 4.24 & 0.80 & 84.80 & 11.95 & 0.00 & 6 \\
\hline 3. & Selection of material that is unsuitable for existing climatic conditions & 3.83 & 0.94 & 76.60 & 6.71 & 0.00 & 9 \\
\hline 4. & $\begin{array}{l}\text { Using materials not of acceptable quality and conforming to the specifica- } \\
\text { tions or design }\end{array}$ & 4.34 & 0.72 & 86.80 & 14.33 & 0.00 & 4 \\
\hline 5. & Using of expired material (cement) & 4.41 & 0.90 & 88.20 & 11.98 & 0.00 & 1 \\
\hline 6. & Using of corroded steel or second-hand reinforcement steel & 4.36 & 1.02 & 87.20 & 10.16 & 0.00 & 3 \\
\hline 7. & Erosion of mortar joint in mason works & 4.07 & 0.88 & 81.40 & 9.30 & 0.00 & 8 \\
\hline 8. & Lack of using sulfate resistance cement in areas exposed to sulfate attack & 4.21 & 0.79 & 84.20 & 11.64 & 0.00 & 7 \\
\hline \multirow[t]{2}{*}{9.} & Using inadequate concrete mix design for structural elements & 4.34 & 0.75 & 86.80 & 13.45 & 0.00 & 5 \\
\hline & Construction materials-related factors & 4.25 & 0.62 & 85.05 & 15.54 & 0.00 & \\
\hline
\end{tabular}


according to their importance in construction process from the respondents' perspectives.

The last ranked factor in this group was the factor of selection of material that is unsuitable for existing climatic conditions with a relative weight of $76.60 \%$. This factor had the least importance because there is not severe climate condition in Gaza Strip.

\subsection{Construction equipment-related factors affecting the defects occurrence in the construction stage}

Referring to Table 6, it is clear that the arithmetic mean of all factors was larger than the overall average (3). Therefore, there were significant differences between construction equipment-related factors. The relative weight of the total axis reached $83.28 \%$, the mean was 4.16 and the standard deviation was 0.66 .

It is clear from Table 6 that the first place was to the factor of lack of required equipment, the second place to the factor of inadequate performance of equipment and the third place to the factor of improper use of equipment with relative weights of $86.20 \%, 84 \%, 79.60 \%$, respectively. The construction equipments as concrete pumps, concrete mixers, vibrator, compactor... etc., are very important factors affecting the defects occurrence; the absence of these tools will lead to improper construction process, especially during concrete casting or soil backfilling. Waziri [22] and Assaf et al. [26] results assured also the importance of construction equipment factors.

\subsection{Comparison of main group factors leading to defects occurrence in the construction of residential buildings in Gaza Strip}

It can be seen that the arithmetic mean of all factors was larger than the overall average (3) (Table 7). Therefore, there were significant differences between the factors. It was found that the rank of the importance of each main factor is as follows: (1) factors due to construction materials, (2) factors due to construction inspection, (3) factors due to construction equipment, (4) factors due to construction and (5) factors due to construction management.

It is clear that factors due to construction materials were ranked first with a relative weight of $85.05 \%$. This result agreed with [23] study results, which is logical because the mainstay of the construction process is the materials; materials with good quality will lead to good construction process and vice versa. The absence of inspection process in most of the residential buildings' construction process in Gaza Strip makes it an important factor, which ranked second with a relative weight of $84.75 \%$. In addition, construction equipment factors were ranked third with relative weight of $83.28 \%$, construction equipment is associated

Table 6 Statistical characteristics for the main construction equipment-related factors

\begin{tabular}{|c|c|c|c|c|c|c|c|}
\hline No. & Construction equipment-related factors & Mean & SD & $\begin{array}{l}\text { Relative } \\
\text { weight } \\
\%\end{array}$ & Value of the test & $P$ Value & Rank \\
\hline 1. & $\begin{array}{l}\text { Improper use of equipment (compactor, concrete pump, vibrator, concrete } \\
\text { mixer, drill, plumb bob...etc.) }\end{array}$ & 3.98 & 0.82 & 79.60 & 9.21 & 0.00 & 3 \\
\hline 2. & $\begin{array}{l}\text { Inadequate performance of equipment (compactor, concrete pump, vibrator, } \\
\text { concrete mixer, drill...etc.) }\end{array}$ & 4.20 & 0.69 & 84.00 & 13.41 & 0.00 & 2 \\
\hline \multirow[t]{2}{*}{3.} & $\begin{array}{l}\text { Lack of required equipment (vibrator, drill, mixer, compactor, cutting disk, } \\
\text { plumb bob...etc.) }\end{array}$ & 4.31 & 0.88 & 86.20 & 11.44 & 0.00 & 1 \\
\hline & Construction equipment-related factors & 4.16 & 0.66 & 83.28 & 13.50 & 0.00 & \\
\hline
\end{tabular}

Table 7 Statistical characteristics for group factors leading to defects occurrence in the construction of residential buildings

\begin{tabular}{|c|c|c|c|c|c|c|c|}
\hline No. & $\begin{array}{l}\text { Factors leading to defects occurrence in the } \\
\text { construction of residential buildings }\end{array}$ & Mean & SD & $\begin{array}{l}\text { Relative } \\
\text { weight \% }\end{array}$ & Value of the test & $P$ value & Rank \\
\hline 1. & Civil construction-related factors & 4.12 & 0.74 & 82.40 & 11.60 & 0.00 & 4 \\
\hline 2. & Construction inspection-related factors & 4.24 & 0.80 & 84.75 & 11.85 & 0.00 & 2 \\
\hline 3. & Construction administration-related factors & 3.97 & 0.56 & 79.36 & 13.18 & 0.00 & 5 \\
\hline 4. & Construction materials-related factors & 4.25 & 0.62 & 85.05 & 15.54 & 0.00 & 1 \\
\hline \multirow[t]{2}{*}{5.} & Construction equipment-related factors & 4.16 & 0.66 & 83.28 & 13.50 & 0.00 & 3 \\
\hline & $\begin{array}{l}\text { Factors leading to defects occurrence in the } \\
\text { construction of residential buildings }\end{array}$ & 4.15 & 0.57 & 82.97 & 15.41 & 0.00 & \\
\hline
\end{tabular}


to construction materials in importance. The fourth and fifth places were to civil construction factors and construction administration factors with relative weights of $82.40 \%$ and $79.36 \%$, respectively; they were the least important factors when comparing with the other first ranked factors; however, they are very important for themselves.

\section{Conclusion}

The research findings identified five groups of factors derived after reviewing the literature and conducting the pilot study. These factors are ranked based on the respondents opinions' relative weights, which are: factors due to construction materials containing nine subfactors, factors due to construction inspection containing four subfactors, factors due to construction equipment containing three subfactors, factors due to construction containing 13 subfactors and factors due to construction management containing 15 subfactors, and all of them are ranked according to their importance by the respondents' opinions.

From respondents' perspective, materials and inspection are the most important factors during construction and this is logical because materials such as concrete and steel are the backbone of buildings and any defect in these materials will lead to defects in the whole building and may cause building's failure in some cases. Inspection plays also an essential role in preventing and eliminating construction defects, and it is well known that almost all the residential building projects in Gaza Strip are executed without soil and construction materials inspection due to lack of awareness and its importance by buildings owners due to their high cost. In Gaza Strip, no attention is paid by many owners to the use of ready mix concrete and concrete equipments such as concrete pumps, vibrator, concrete mixer and steel bending tool are very necessary during construction; the absence of these equipments leads to problems such as concrete segregation, bleeding, weak concrete mix and reinforcement appearance. Well construction methods, qualified and skilled labors, wellexperienced management, following and monitoring are important issues during construction, and applying them will contribute to elimination of construction defects.

\subsection{Recommendations}

From the above conclusions, the following suggestions are recommended for the firms and regulatory authorities:

1. It is strongly recommended to apply a strict quality assurance and quality control (QA/QC) program for the designer and contractor to ensure commitment of the specifications, standards, conditions and instructions.
2. It is strongly recommended for the related authorities (engineering association and local municipalities) to activate the familiar insurances (well construction or well execution insurance and the maintenance insurance) for the informal sectors the same as in the formal sectors.

3. According to the findings of this study, the most significant cause for the building defects and failures was found to be the low quality of construction material. Therefore, it is necessary to hire a third party (consultant) who will be responsible to test and approve all the materials prior to use by the contractor.

4. For improving the productivity of residential building construction's workers, it is necessary and important to conduct building activities' training and education. Training of workers should be on a regular basis. This can be in the form of on-the-job training, workshops, seminars or conferences. Also, there is a need to increase awareness in owners toward conducting materials inspections before using them in the construction process.

5. Further awareness is needed on the risk associated with involvement of unqualified people in construction activities. The presence of more qualified and well-experienced structural engineers and civil engineers is required, without whom work quality on-site cannot be guaranteed.

\subsection{Limitations and future studies}

The findings of this study provide useful insights to the firms and regulatory bodies to deal with the critical factors affecting defect occurrence in the construction phase of the residential buildings. This study focuses on the Gaza Strip and has predetermined the grouping of factors. Future scholars may apply this study in other countries for further generalizability of the results. The scholars may use other statistical approaches to analyze the data, for example, factor analysis, in order to group the factors. The developed components may represent the underlying factors for defects in the study's local construction industry.

\section{Compliance with ethical standards}

Conflict of interest The authors declare that they have no conflict of interest.

\section{References}

1. Sherbinin AD et al (2007) Population and environment. Annu Rev Environ Resour 32:345-373 
2. Akadiri PO et al (2012) Design of a sustainable building: a conceptual framework for implementing sustainability in the building sector. Buildings 2:126-152

3. Allotey SE (2014) An evaluation of the impact of defects in public residential buildings in Ghana. Civ Environ Res 6:58-64

4. Alencastro $J$ et al (2018) The relationship between quality defects and the thermal performance of buildings. Renew Sustain Energy Rev 81:883-894

5. Rotimi FE et al (2015) Evaluating defect reporting in new residential buildings in New Zealand. Buildings 5:39-55

6. Aljassmi $\mathrm{H}$ et al (2013) Project pathogens network: new approach to analyzing construction-defects-generation mechanisms. J Constr Eng Manag 140:04013028

7. Ali AS, Wen KH (2011) Building defects: possible solution for poor construction workmanship. J Build Perform 2:12

8. Josephson P-E, Saukkoriipi L (2005) Slöseri i byggprojekt: behov av förändrat synsätt. External Organization

9. Ahmad $\mathrm{Z}$ et al (2018) Building information modeling as a risk transformer: an evolutionary insight into the project uncertainty. Autom Constr 92:103-119

10. Barber $P$ et al (2000) Quality failure costs in civil engineering projects. Int J Qual Reliab Manag 17:479-492

11. Burati JL Jr et al (1992) Causes of quality deviations in design and construction. J Constr Eng Manag 118:34-49

12. Georgiou J et al (2000) A review of builder registration in the State of Victoria, Australia. Struct Surv 18:38-46

13. Hillman Willis T, Willis WD (1996) A quality performance management system for industrial construction engineering projects. Int J Qual Reliab Manag 13:38-48

14. Josephson P-E, Hammarlund Y (1999) The causes and costs of defects in construction: a study of seven building projects. Autom Constr 8:681-687

15. Josephson P-E et al (2002) Illustrative benchmarking rework and rework costs in Swedish construction industry. J Manag Eng 18:76-83

16. Love PE, Smith J (2003) Benchmarking, benchaction, and benchlearning: rework mitigation in projects. J Manag Eng 19:147-159

17. Mills A et al (2009) Defect costs in residential construction. J Constr Eng Manag 135:12-16

18. Son J, Rojas EM (2010) Impact of optimism bias regarding organizational dynamics on project planning and control. J Constr Eng Manag 137:147-157

19. Chong W-K, Low S-P (2005) Assessment of defects at construction and occupancy stages. J Perform Constr Facil 19:283-289

20. Matousek M (1985) A system for a detailed analysis of structural failures. In: Proceedings of the 3rd international conference on structural safety and reliability

21. Jingmond $\mathrm{M}$, Ågren $\mathrm{R}$ (2015) Unravelling causes of defects in construction. Constr Innov 15:198-218

22. Waziri BS (2016) Design and construction defects influencing residential building maintenance in Nigeria. Jordan J Civ Eng 10:12
23. Ahzahar $\mathrm{N}$ et al (2011) A study of contribution factors to building failures and defects in construction industry. Procedia Eng 20:249-255

24. Bakri NNO, Mydin MAO (2014) General building defects: causes, symptoms and remedial work. Eur J Technol Des 12:4-17

25. Al-Farra MZ (2011) Improving the tender document conditions to minimize the building maintenance in Gaza Strip. Master Thesis, Islamic University of Gaza

26. Assaf $S$ et al (1996) Effects of faulty design and construction on building maintenance. J Perform Constr Facil 10:171-174

27. Russen S (2004) The practice of business statistics: using data for decisions. In: Moore David S, McCabe George P, Duckworth William M, Sclove Stanley L (eds) The mathematical Gazette, vol 88. W. H. Freeman, New York, pp 390-391. ISBN 142922150X

28. Chong W-K, Low S-P (2006) Latent building defects: causes and design strategies to prevent them. J Perform Constr Facil 20:213-221

29. Cogurcu M (2015) Construction and design defects in the residential buildings and observed earthquake damage types in Turkey. Nat Hazards Earth Syst Sci 15:12

30. Dahanayake B, Ramachandra T (2016) Assessment on defects occurence and rework costs in housing construction sector in Srilanka. Context 19:86

31. Ojo A, Ijatuyi O (2014) Defective construction in residential buildings: a study of sunshine gardens, Akure Nigeria. Int J Civ Eng Constr Estate Manag 1:16-30

32. Olanrewaju ALA et al (2010) Quantitative analysis of defects in Malaysian university buildings: providers' perspective. J Retail Leis Prop 9:137-149

33. Sivanathan $S$ et al (2012) An overview of design deficiencies on building maintenance. OIDA Int J Sustain Dev 5:105-112

34. Watt DS (2009) Building pathology: principles and practice. Wiley, New York

35. Tayeh B et al (2016) Effects of faulty design phase on school buildings maintenance in Gaza Strip. Am J Civ Eng Archit 4:199-210

36. Tayeh BA et al (2018) Factors affecting the success of construction projects in Gaza Strip. Open Civ Eng J 12:10

37. Maqsoom A et al (2018) Intrinsic psychosocial stressors and construction worker productivity: impact of employee age and industry experience. Econ Res 31:1880-1902

Publisher's Note Springer Nature remains neutral with regard to jurisdictional claims in published maps and institutional affiliations. 